\title{
Gallery character of porous space in the STI-type zeolite structure
}

\section{Галериен характер на поровото пространство в STI-тип зеолитна структура}

\section{Tsveta Stanimirova, Georgi Kirov \\ Цвета Станимирова, Георги Киров}

University of Sofia St. Kliment Ohridski, Dept. Mineralogy, Petrology and Economic Geology, 15 Tzar Osvoboditel Blvd., 1000 Sofia; E-mail: stanimirova@gea.uni-sofia.bg

\begin{abstract}
The existence of a specific gallery type of zeolite framework is confirmed. It has been found that similar to HEU-type, STI-type framework can be represented as a layered structure in which two impermeable to water molecules and exchange cations aluminum-silicate layers, separated by diortho-groups, confined gallery-type of porous free space, which is available for extra-framework components migration in all directions in the plane of the interlayer.
\end{abstract}

Keywords: STI-type zeolite framework, gallery space.

\section{Introduction}

Zeolites are hydrated aluminum-silicates of alkali and alkaline earth metals with a framework structure. Zeolite frameworks are composed of cornersharing $\mathrm{TO}_{4}$ tetrahedra (where $\mathrm{T}$ is either $\mathrm{Si}$ or $\mathrm{Al}$ ), forming a system of connected cavities and channels, which are specific for each structural type. Water molecules and alkaline and/or alkaline earth cations are located in cavities or channels for compensation of negative framework charge, caused by substitution $\mathrm{Si}^{4+}-\mathrm{Al}^{3+}$.

Typically, zeolite pore systems are defined as "channel" or "cage" types. In the first type, at least in some distinct parts, the channels are isolated from the adjacent channels with a barrier of $\left[(\mathrm{Si}, \mathrm{Al}) \mathrm{O}_{4}\right]_{\mathrm{n}}$ construction that is impassable to the extra-framework components. In the "cage" type zeolite structures, the framework is made up of spheroidal or ellipsoidal cages (caves). The individual cages are connected through 8- to 12-membered rings permeable for water molecules. The directions connecting cage (cave) centers are considered as "channel" directions.

The problem of defining the topological character of the porous space ("cage" or "channel") is of a fundamental importance for understanding the transport capabilities of the pore system and the state of the confined solution. According to contemporary ideas, water enclosed in nano-sized volumes has very different properties from those in bulk volumes. Modern experimental research and computer models show that when the ratio of the pore surface to its volume becomes very large, the importance of the "matrix": dimensions, shape, symmetry, charge, and charge distribution, is greatly increased. This requires special attention to the specifics of the given pore system in the aim to find the most suitable applications.

In recent work (Kirov et al., 2020) we showed that representatives of the group of plate zeolites those with the structures of HEU type (heulandite and clinoptilolite), can be described as a gallery type of zeolite structure, along with the channel and cages structure types. The structural topology of the tetrahedral HEU-framework is usually described to possess C $2 / \mathrm{m}$ space group symmetry and two channels confined by 10 -member and 8 -member tetrahedral rings parallel to the c-axis (channels A and B) intersecting with an 8-membered channel parallel to [100] (channel C). In this way, a two-dimensional channel system is formed parallel to (010), and a layer-like structure (Fig. 1a). The paper of Kirov et al. (2020) draws attention 
to the fact that the channels thus formulated are in no part separated from each other by impassable barriers for water molecules and cations, and two intersecting channels cover almost the entire interlayer area. The main construction components of the HEU-type structure can be represented by twolayered aluminium-silicate packets, impassable by extra-framework cations and water molecules, which include 28 of the 36-tetrahedron of a unit cell and are linked with $4(\mathrm{Si}, \mathrm{Al})_{2} \mathrm{O}_{7}$ diortho-groups. Thus, the framework structure of the heulandite and clinoptilolite is very similar to the structure of pillared clay and the space between the layers can be described in the terminology of the pillared clay as a gallery or a gallery space (Schoonheydt et al., 1999). The gallery space is a continuous flat gap between two aluminum-silicate layers (interlayer) supported by diortho-groups $(\mathrm{Al}, \mathrm{Si})_{2} \mathrm{O}_{7}$, which break it into rectilinear lanes (corridors, channels) confined by 10 - and 8 -membered tetrahedral rings. The projection of the bridge oxygen (of the diortho-groups) in the plane (010) gives a clear idea of the "logistic" possibilities for migration of molecules and cations in the pore space. Each cage has been shown to provide a specific confinement environment and is preferred by particular cationwater assemblages (CWA) or water assemblages (WA)), as first recognized in the structures of heulandite and clinoptilolite.

In this work, we show the gallery character of the framework of another representative of the zeolites with plate crystal morphology - the STI-type framework.

\section{Results}

The STI-type framework includes four mineral species (Coombs et al., 1997):

1) stellerite: $\left|\mathrm{Ca}_{8}\left(\mathrm{H}_{2} \mathrm{O}\right)_{56}\right|\left[\mathrm{Al}_{16} \mathrm{Si}_{56} \mathrm{O}_{144}\right]$, SG Fmmm; (Galli, Alberti, 1975a);

2) stilbite-Ca: | $\left(\mathrm{Ca}_{0.5}, \mathrm{Na}, \mathrm{K}\right)_{18}\left(\mathrm{H}_{2} \mathrm{O}\right)_{60} \mid\left[\mathrm{Al}_{18} \mathrm{Si}_{54} \mathrm{O}_{144}\right]$ SG F2/m, (Slaugther, 1970);

3) stilbite-Na: $\left|\left(\mathrm{Na}, \mathrm{Ca}_{0.5}, \mathrm{~K}\right)_{18}\left(\mathrm{H}_{2} \mathrm{O}\right)_{52}\right|\left[\mathrm{Al}_{18} \mathrm{Si}_{54} \mathrm{O}_{144}\right]$, $\mathrm{SG} \mathrm{F} 2 / \mathrm{m}$;
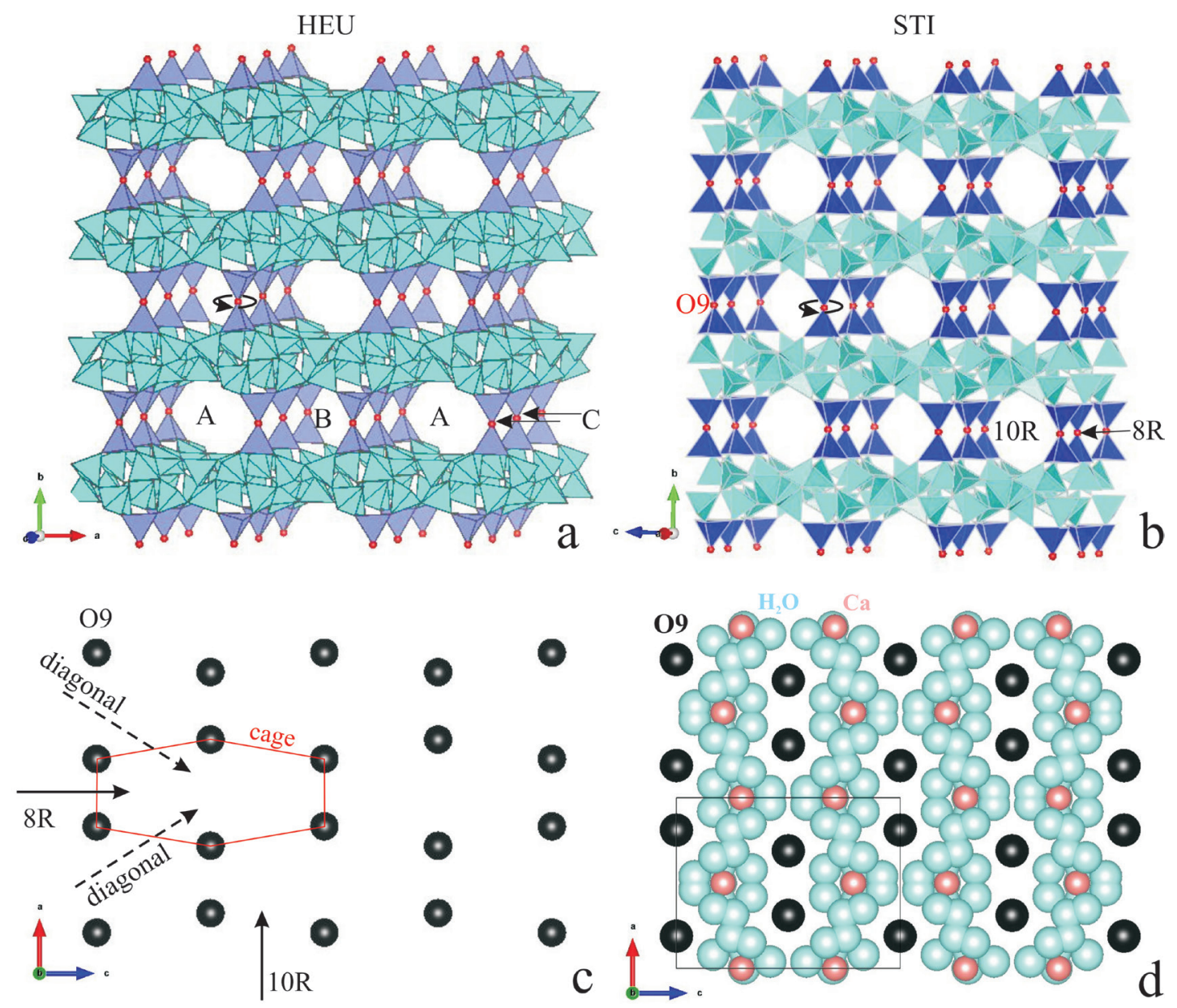

Fig. 1. Gallery representation of the zeolite type structure: $a$ ) overall view of the HEU framework; $b$ ) overall view of the STI framework; c) distribution of $\mathrm{O} 9$ atoms in STI framework and 10R, 8R, and two diagonal directions, forming hexagonal cage; d) distribution of $\mathrm{O} 9$ atoms and location of the extra-framework $\mathrm{Ca}^{2+}$ and water in gallery porous space in STI framework 
4) barrerite: $\left|\left(\mathrm{Na}, \mathrm{Ca}_{0.5}, \mathrm{~K}\right)_{16}\left(\mathrm{H}_{2} \mathrm{O}\right)_{56}\right|\left[\mathrm{Al}_{16} \mathrm{Si}_{56} \mathrm{O}_{144}\right]$ SG Amma; (Galli, Alberti, 1975b).

Stilbite is one of the most common zeolites, while barrerite is very rarely found. Stilbites and/ or stellerites are probably the first zeolite minerals described (Colella, Gualtieri, 2007).

The highest possible symmetry of STI framework-type materials is Fmmm. Stellerite, stilbite, and barrerite show different symmetries because of different extra-framework cations and also different distributions within the zeolitic cages. Conventionally, the framework is described as constituted by two systems of interconnected channels: one parallel to [001], confined by 8 -membered rings (free dimensions $2.7 \times 5.6 \AA$ ), and the other running parallel to [100], formed by 10 -membered rings of tetrahedra $(4.7 \times 5.0 \AA)$, forming a two-dimensional channel system parallel to $(010)$. However, the approach used to estimate the pore space of the HEUtype framework shows, that in STI-type framework, likely in the HEU-type, the pore space is between two impermeable to water molecules and cation exchanges aluminum-silicate layers, separated by rows of diortho-groups, which gives it a gallery character (Fig. 1b). In this case, the extra-framework cations and water molecules can freely change the direction of migration at any point in the interlayer. This can be seen very clearly in the projection of the bridge oxygen $\mathrm{O} 9$ of the diortho-groups (Fig. 1c). The "pillaring" diortho-groups break the pore space of elongated hexagonal cages formed by the intersection of two 10-membered channels (along with $\boldsymbol{a}$ ) with one eight-membered channel along with $\boldsymbol{c}$. On the diagonals of the unit cell, two other directions for the migration of cations and molecules are outlined. Thus, the entire pore space is available for migration in all directions in the plane of the interlayer, as the interlayer is almost completely covered by overlapping channels. For example, if we look at the calcium position, we see that there are various possibilities for migration of extra-framework components $(\mathrm{Ca}$ cations and the water molecules) in all directions around $\mathrm{O} 9$ in the plane of the gallery (Fig. 1d). In the STI-type framework, at least four positions occupied by monovalent or divalent cations in natural and ion-exchanged samples have been established in the pore space (Seryotkin, Bakakin, 2019). In all cases, the cation positions are located at the level of bridging oxygen atoms $\mathrm{O} 9$ in the interlayer, which predetermines this type of mobility of all components. The comparison of the features of the gallery space of STI and HEU, reveals that despite the similar size of the tetrahedral rings in both types of structures, the STI-type framework is significantly more open to guest molecules than the HEU framework, since the framework density of STI is 16.3 tetrahedra per $1000 \mathrm{~A}^{3}$, against 17.1 tetrahedra per
$1000 \mathrm{~A}^{3}$ of heulandite. However, in both zeolite structural types (STI and HEU), the representation of the pore space as gallery and the structure as layered one explains the plate morphology of the crystals and the perfect cleavage in the direction of the gallery, perpendicular to the diortho-groups.

\section{Conclusion}

The existence of a specific gallery type of zeolite framework is confirmed. Signs for the relation of a given structure to the gallery type are outlined. Future research is needed to establish more structures related to the gallery type and what features and varieties they have. Specific features of gallery structures such as the environment for interaction of ions and molecules, their logistical capabilities and limitations, as well as CWA and CA in the interlayer must be established.

Acknowledgments: The authors thank for the support provided by Project BG05M2OP0011.002-0019: "Clean Technologies for a Sustainable Environment - Water, Waste, Energy for a Circular Economy" (Clean \& Circle) for the construction and development of a Competence Center, funded by the Science Operational Program and Smart Growth Education, co-financed by the European Union through the European Structural and Investment Funds.

\section{References}

Colella, C., A. F. Gualtieri. 2007. Cronsted's zeolites. - Micropor. Mesopor. Mater., 105, 213-221; https://doi.org/ 10.1016/j.micromeso.2007.04.056.

Coombs, D. S., A. Alberti, T. Armbruster, G. Artioli, C. A. Colella, E. Galli, J. D. Grice, F. Liebau, J. A. Mandarino, H. Minato, E. H. Nickel, E. Passaglia, D. R. Peacor, S. Quartieri, R. Rinaldi, M. Ross, R. A. Sheppard, E. Tillmanns, G. Vezzalini.1997. Recommended nomenclature for zeolite minerals: Report of the subcommittee on zeolites of the International Mineralogical Association, Commission on New Minerals and Mineral Names. - Can. Mineral., 55, 1571-1606.

Galli, A., A. Alberti. 1975a. The crystal structure of stellerite. - Bull. Mineral., 98, 11-18; https://doi.org/10.3406/ bulmi.1975.6952.

Galli, A., A. Alberti. 1975b. The crystal structure of barrerite. - Bull. Mineral., 98, 331-340; https://doi.org/10.3406/ bulmi.1975.7013.

Kirov, G., L. Dimova, Ts. Stanimirova. 2020. Gallery character of porous space and local extra-framework configuration in the HEU-type structures. - Micropor. Mesopor. Mater., 293, 109792; https://doi.org/10.1016/j.micromeso. 2019.109792.

Schoonheydt, R. A., T. Pinavaia, G. Lagali, N. Gangas. 1999. Pillared clays and pillared layered solids. - Pure Appl. Chem., 71, 2367-2371; https://doi.org/10.1351/ pac199971122367.

Seryotkin, Y. V., V. V. Bakakin. 2019. Structure of K,Naexchanged stellerite zeolite and its evolution under high pressures. - J. Struct. Chem., 60, 1612-1621; https://doi. org/10.1134/S0022476619100068.

Slaugther, M. 1970. Crystal structure of stilbite-Am. Mineral., $55,387-397$. 